\title{
Primary torsion and necrosis of the vermiform appendix in a child: A case report
}

\section{Çocukta vermiform apendiksin primer torsiyon ve nekrozu: Olgu sunumu}

\author{
Birsen HARMA
}

ABSTRACT

Acute appendicitis is the most common cause of acute abdominal pain orienting on the right lower quadrant in children. Some other conditions including torsion of the vermiform appendix can simulate acute abdomen. A three-year- old female child was reported to be suffering from acute right abdominal pain. During the routine appendectomy procedure, necrotic vermiform appendix was found which was twisted in clockwise direction. To the best of our knowledge, our patient is the youngest one among cases with twisted vermiform appendicitis that had been reported in the literature.

Keywords: Necrosis, appendix, child öz

Akut apendisit çocuklarda akut sağ alt kadran ağrısının en sık etiyolojisidir. Torsiyone vermiform apendiks gibi bazı nedenler de akut batın tablosunu taklit edebilmektedir. Bu makalede akut sağ alt kadran ağrısı ile görülen ve akut apendisit tanısı alan 3 yaşında bir kız çocukta karşılaşılan saat yönünde torsiyone olmuş ve nektotik vermiform apendiks bildirilmektedir. Ilgili literatür ışığında görüldüğü kadarıyla 3 yaşındaki bu olgu nekrotik torsiyone vermiform apendiks olguları içinde bu güne kadarki en küçük olgudur.

Anahtar kelimeler: Nekroz, apendiks, çocuk

\section{INTRODUCTION}

Acute appendicitis is the most common cause of acute abdominal pain localized on the right lower quadrant in children. Some other conditions including torsion of the vermiform appendix can also simulate acute abdomen. Torsion and necrosis of the vermiform appendix are rarely seen in children. The signs and symptoms are similar to that of acute appendicitis and the diagnosis is usually made at the time of surgery ${ }^{1}$. There have been few and sporadic descriptions of these conditions in the international literature since the initial description by Payne in $1918^{1-7}$. To the best of our knowledge this case is the youngest one among the patients with primary torsion and necrosis of the vermiform appendix reported to date.

\section{CASE REPORT}

A 3-year-old girl presented with acute right lower quadrant pain that started six hours ago. Her family sta- ted that she was vomited two times. On initial examination she was afebrile, agitated and uncomfortable even at rest. Blood examination showed white blood count of $23.000 / \mathrm{mm}^{3}$ with $24 \%$ neutrophils, and $76 \%$ lymphocytes. Hemoglobin was $11.6 \mathrm{~g} / \mathrm{dL}$. Urine microscopy was normal. Plain abdominal radiograms showed no abnormality. Abdominal ultrasonography revealed free fluid and distended, edematous nonperistaltic and noncompressible $7.5 \mathrm{~cm}$-long appendix. Based on her history and physical examination findings, the patient was diagnosed as having acute appendicitis and underwent appendectomy. Intraoperatively necrotic vermiform appendix was found which was twisted clockwise about 360 degrees. About $25 \mathrm{ml}$ of seroanguinous fluid was found in the peritoneal cavity. Appendectomy was performed and no other intraabdominal pathology was noted. Histology showed ischemic infarct areas of the edematous appendix. Her postoperative history was uneventful and she was discharged on postoperative third day.

Received: 11.01 .2016

Accepted: 04.02.2016

Malatya Goverment Hospital Pediatric Surgery Department

Yazışma adresi: Birsen Harma, Malatya Goverment Hospital, Department of Pediatric Surgery, Malatya

e-mail: birsenharma@gmail.com 


\section{DISCUSSION}

Torsion and necrosis of vermiform appendix is a very rare condition in children which simulates acute appendicitis. Since the first description of the torsion of vermiform appendix by Payne in $1918^{2}$ there are few reports about pediatric cases. Even most of them were

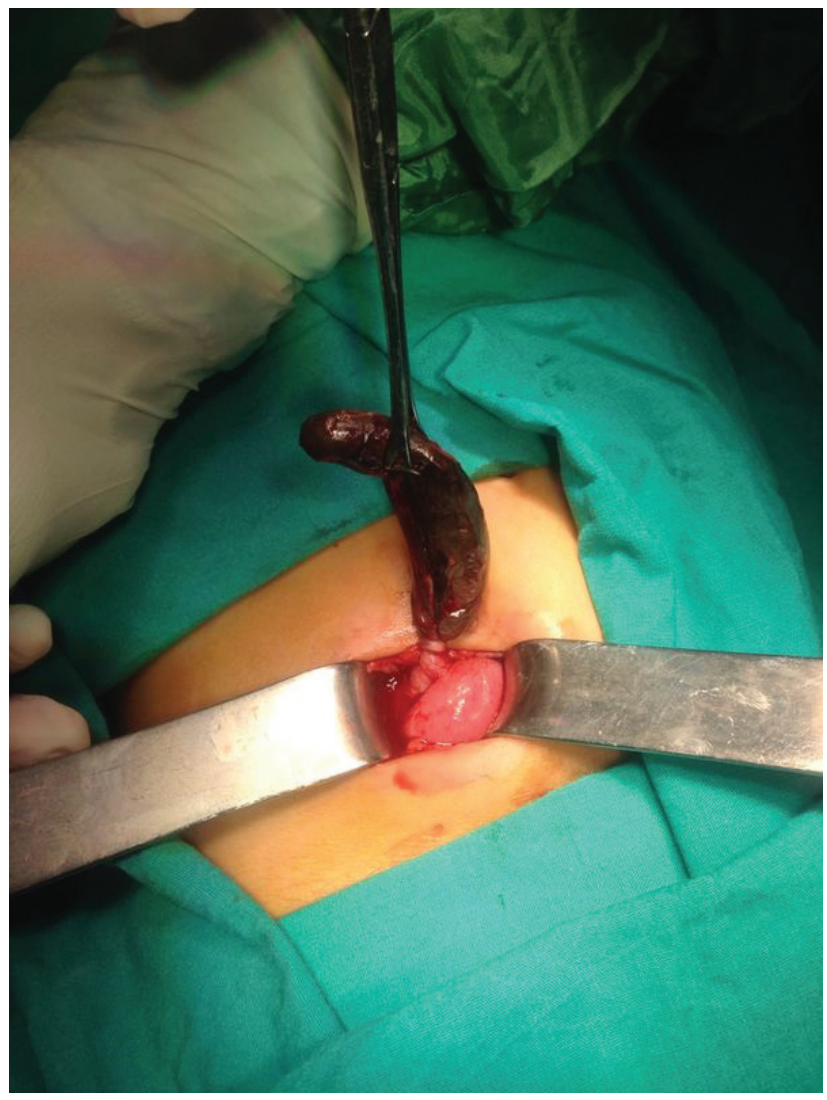

Figure 1. Ischemic appearance of the twisted appendix.

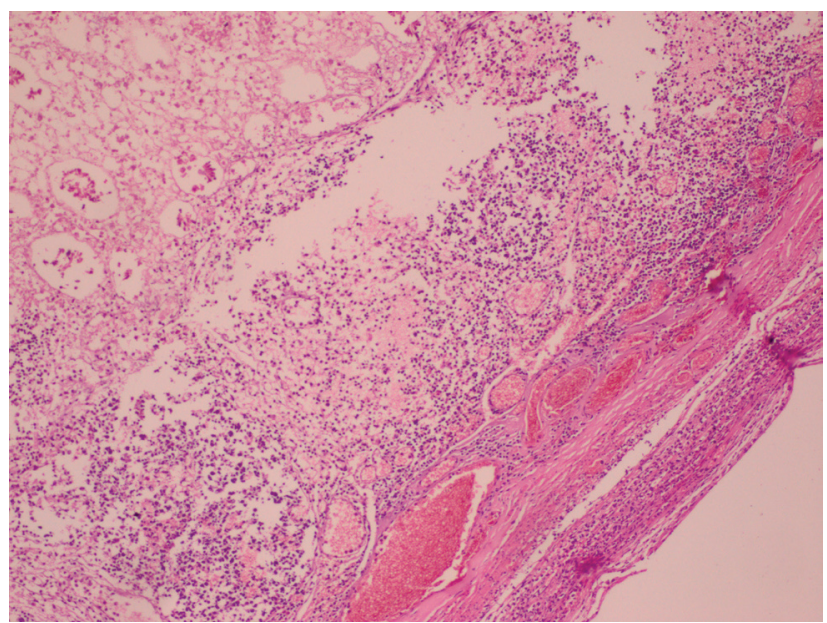

Figure 2. Histological examination showed ischemic infarct areas of the odematous appendix. secondary torsions (lipomas, mucoceles) ${ }^{8,9}$. In all cases the clinical condition was indistinguishable from acute appendicitis ${ }^{7}$. The site of the torsion is most frequently $\geq 1 \mathrm{~cm}$ away from the appendiceal basis. Even the direction of the rotation is most frequently anticlockwise ${ }^{10}$, in our case appendix was rotated clockwise direction. Malik ${ }^{11}$ states that the infarcted appendix has a characteristic sonographic appearance as a hyperechoic noncompressible ovoid structure near the colonic wall.

The aetiology of the condition is uncertain. Merrett et al. ${ }^{12}$ suggested several hypothesis to explain this event in their review letter. It is uncertain if the inflammation causes torsion of the appendix or vice versa.

\section{CONCLUSION}

Torsion and necrosis of the vermiform appendix is an extremely rare pathological entitiy in children and it is indistinguishable from acute appendicitis.

\section{REFERENCES}

1. Gopal K, Kumar S, Grewal H. Torsion of the vermiform appendix. J Pediatr Surg 2005;40:446-447. http://dx.doi.org/10.1016/j.jpedsurg.2004.10.027

2. Payne JE. A case of torsion of the appendix. Br J Surg 1918;6:327. http://dx.doi.org/10.1002/bjs.1800062216

3. Mohammad W, Azfar M. Torsion of the vermiform appendix: Report of a case and Rewiew of the literature. The Internet Journal of Surgery 2007;17:2.

4. Christianakis E, Paschalidis N, Flippou G, Smailis D, Chorti $\mathrm{M}$, Rizos S et al. Cecal epiploica appendix torsion in a female child mimicking acute appendicitis: a case report. Cases Journal 2009;2:8023.

http://dx.doi.org/10.1186/1757-1626-2-8023

5. Bari S, Sheikh KA, Malik AA. Torsion of an epiploic appendix mimicking acute appendicitis. Int J Surg 2008:6:488-489. http://dx.doi.org/10.1016/j.ijsu.2006.07.006

6. Gilchrist BF. Torsion of the appendix. Journal Pediatr Surg 1995;30(6):901-902.

http://dx.doi.org/10.1016/0022-3468(95)90781-5

7. Bestman TJR, Cleemput M, Detournay G. Torsion of the vermiform appendix: a case report. Acta Chir Belg 2006;106:228-229. http://dx.doi.org/10.1080/00015458.2006.11679878

8. Killam AR. An unusual cause of appendicitis: torsion produced by a mesoappendiceal lipoma. Am Surg 1969;35:684-689.

9. Legg NG. Rare cases of intestinal obstruction. Torsion complicating mucocele of the appendix. JR Coll Surg Edinb 1973;18:236.

10. Val-Bernai JF, Gonzalez-Vela C, Garijo MF. Primary acute torsion of the vermiform appendix. Pediatr Pathol Lab Med 1996;16:655-661. http://dx.doi.org/10.1080/15513819609168701

11. Malik KA. Torsion of an Epiploic Pretending as Acute Appendicitis. Omman Medical Journal 2010;25(3):225-226.

12. Merrett ND, Lubowski DZ, King DW. Torsion of the vermiform appendix: a case report and rewiev of the literature. Aust J Surg 1992:62:981-983.

http://dx.doi.org/10.1111/j.1445-2197.1992.tb07661.x 